\title{
Dzieje zagospodarowania mienia poewangelickiego w Osiecznej po 1945 r.
}

\begin{abstract}
Słowa kluczowe: Osieczna, mienie poewangelickie, świątynia, parafia, nacjonalizacja, nieruchomość, wyposażenie

Key words: Osieczna, post-Evangelical property, temple, parish, nationalization, immovable, furnishings
\end{abstract}

I. Wstęp. II. Świątynia. III. Dom pastora, szpital-przytułek, dom towarzystw niemieckich. IV. Własność ziemska. V. Mienie ruchome. VI. Podsumowanie

\section{Wstęp}

Ofensywa Armii Czerwonej na przełomie 1944 i 1945 r. wraz z późniejszymi decyzjami politycznymi przemodelowała dotychczasowe ziemie polskie i tzw. Ziemie Odzyskane, m.in. pod względem wyznaniowym. Głębokie przemiany dotknęły wówczas Kościoły ewangelickie, działające wcześniej na terenie drugiej Rzeczypospolitej (także w okresie 1939-1945) i wschodniej Rzeszy Niemieckiej, których tradycja sięgała nierzadko w odległą, poreformacyjną przeszłość (XVI/XVII w.). Ewakuacja ludności niemieckiej zimą 1944/1945 r. doprowadziła do wyludnienia i zamarcia życia religijnego w wielu parafiach ewangelickich. W miejscowościach pozostały dobra kościelne ruchome i nieruchome, których zarządem i zagospodarowaniem zajęły się tworzące się powojenne władze polskie i kościelne różnych wyznań chrześcijańskich (najczęściej rzymskokatolickie, ale też metodystyczne, polsko-katolickie, prawosławne).

Mienie poewangelickie jest przedmiotem badań i publikacji naukowych ${ }^{1}$, a także tematem zainteresowania regionalistów, nierzadko przyczyniających się do popularyzacji i zachowania pamięci o bytności, kulturze materialnej i duchowej byłych mieszkańców - ewangelików². Zagadnienie to nadal jednak nie zostało dostatecznie opracowane, co można zaobserwować szczególnie w ujęciu jednostkowym — historii poszczególnych parafii bądź superintendentur.

Niniejszy artykuł stanowi uzupełnienie wspomnianej luki. Poświęcony jest historii jednej z byłych parafii ewangelicko-unijnych należących do superintendentury Leszno (Lissa), parafia Osieczna ${ }^{3}$. W tekście zaprezentowane zostaną losy mienia parafialnego po drugiej wojnie światowej, rozpatrywanego w aspekcie nowego zagospodarowania (użytkowania). Przedstawione zostaną dzieje świątyni, zabudowań i ziem parafialnych oraz niektórych ruchomości — elemen-

1 Suchecka G. 1998; Szczudłowski P. 2001; Małyszka A. 2004; Domasłowski J. 2005; Domasłowski J. 2009; Sroka P. 2010; Kłaczkow J. 2010; Birecki P. 2012; Kurpiewski M. 2013; Kiec O. 2017.

2 Towarzystwo Ziemi Osieckiej, https:/www.facebook.com/Towarzystwo-Ziemi-Osieckiej-349677798761999/ (dostęp 03.11.2019); Błaszkowski Marcin, http://www.marcinblaszkowski.leszno.eu/13.html (dostęp 03.11.2019); Sikora Tomasz i in., https://opuszczone-koscioly-ewangelickie.blogspot.com/ (dostęp 03.11.2019).

\footnotetext{
${ }^{3}$ Grelewski S. 1937, s. 327.
} 
tów wyposażenia świątyni. Po roku 1945 wszystkie one znalazły nowe, świeckie lub kościelne przeznaczenie $^{4}$. W opracowaniu uwzględniono okres od 1945 do 1989 r., sygnalizując jedynie wydarzenia (rewindykację) i sposób ich użytkowania po roku 1989. Podstawę źródłową artykułu stanowią materiały z zasobu Archiwum Państwowego w Lesznie i Instytutu Pamięci Narodowej Oddział w Poznaniu. Są to akta państwowe - Ministerstwa Administracji Publicznej w Warszawie, Urzędu Wojewódzkiego w Poznaniu, Prezydium Miejskiej Rady Narodowej w Osiecznej, Starostwa Powiatowego w Lesznie oraz Zarządu Miejskiego w Osiecznej i in. Dotarcie do ewentualnych archiwaliów Kościoła Katolickiego okazało się niemożliwe (brak odpowiedzi na zapytanie). Według Kościoła Ewangelicko-Augsburskiego, jego dokumentacja nie zawiera istotnych danych; wskazano na zasoby Archiwów Państwowych, które zostały tu wykorzystane. Dla badanych zagadnień istotne były też informacje uzyskane od trzech świadków omawianych wydarzeń, mieszkańców Osiecznej, zwłaszcza relacja pana Józefa Juchniewicza odnośnie do rozbiórki świątyni. Materiały z leszczyńskiego archiwum częściowo są rozproszone; to pojedyncze dane zawarte w dokumentach w różnych jednostkach. Tylko jednostka o sygnaturze 702, z zespołu „Akta miasta Osieczna”, zawiera dokumenty dotyczące mienia poewangelickiego, zebrane w jednej teczce. Generalnie źródeł dotyczących podejmowanego tematu jest niewiele i są one wybiórcze.

\section{II. Światynia}

Neogotycki kościół ewangelicki w Osiecznej, wybudowany w latach 1898-1899 (uroczyste otwarcie 14 grudnia 1899 r., potem jeszcze wykańczany) ${ }^{5}$, służył celom religijnym najprawdopodobniej do stycznia 1945 r., gdy prawie wszyscy członkowie parafii wraz z pastorem opuścili miasto $\mathrm{z}$ powodu zbliżającego się frontu. Życie parafialne w miejscowości zamarło i już nigdy się nie odrodziło ${ }^{6}$.

Nie są znane jakiekolwiek dokumenty ani relacje świadków obrazujące dzieje świątyni od momentu ewakuacji Niemców z miasta do chwili walk o Osiecznę i jej zajęcie przez oddziały Armii Czerwonej 27 stycznia 1945 r. ${ }^{7}$ Nie są znane również jej losy w kolejnych tygodniach i miesiącach. Wiadomo jedynie, iż nie kwaterowały w niej oddziały radzieckie, które zajęły pobliską szkołę powszechną (dawniej ewangelicką), klasztor Zakonu Braci Mniejszych, Zakład św. Józefa (ss. Elżbietanki), a także zamek i kąpielisko miejskie, tzw. Letnisko. Ich poczynań w stosunku do obiektów kościelnych, budynków miejskich oraz jego mieszkańców też nie można odtworzyć ${ }^{8}$. W zachowanych archiwaliach oraz w pamięci historycznej lokalnej społeczności brak świadectw o realiach pobytu wojsk ZSRR w Osiecznej. Zapewne ówczesna poprawność polityczna, wojenna i socjalistyczna cenzura oraz obawa przed „sojusznikiem” skutecznie hamowały ewentualne, negatywne adnotacje w aktach, a ludzkie wspomnienia kierowały ku „właściwie” pojmowanym wydarzeniom historycznym (dramaturgia i brutalność okupacji niemieckiej).

Dalsze, powojenne dzieje kościoła (i całego mienia) wiązały się bezpośrednio z przemianą polityczno-społeczno-narodowościową i wyznaniową dokonującą się w ówczesnej Polsce. Czynniki te spowodowały przeznaczenie osieckich obiektów poewangelickich na cele świeckie i społeczno-gospodarcze użytkowanie.

${ }^{4}$ Cmentarze ewangelickie (Osieczna i okoliczne wsie) nie zostały na nowo zagospodarowane (grabież budulca, dewastacja, zarastanie); władze lokalne nie ubiegały się o przejęcie ich w zarząd, ani w użytkowanie.

5 Evangelischer Volkskalender. 1901, s. 62; Michalski M. 2005, s. 49.

6 Jędraś S. 2012, s. 372.

7 Osiecznę po krótkich, lecz krwawych walkach zajęli żołnierze radzieccy z 1. Frontu Ukraińskiego, 3. Armii Gwardii, 120. Korpusu Armijnego oraz 25. samodzielnego korpusu pancernego. W boju poległo 11 czerwonoarmistów i 5 żołnierzy Wehrmachtu, Bogdanowicz J. 2013, s. 79, 96, 103.

${ }^{8}$ AP Leszno, AO, sygn. 588, b. pag. 


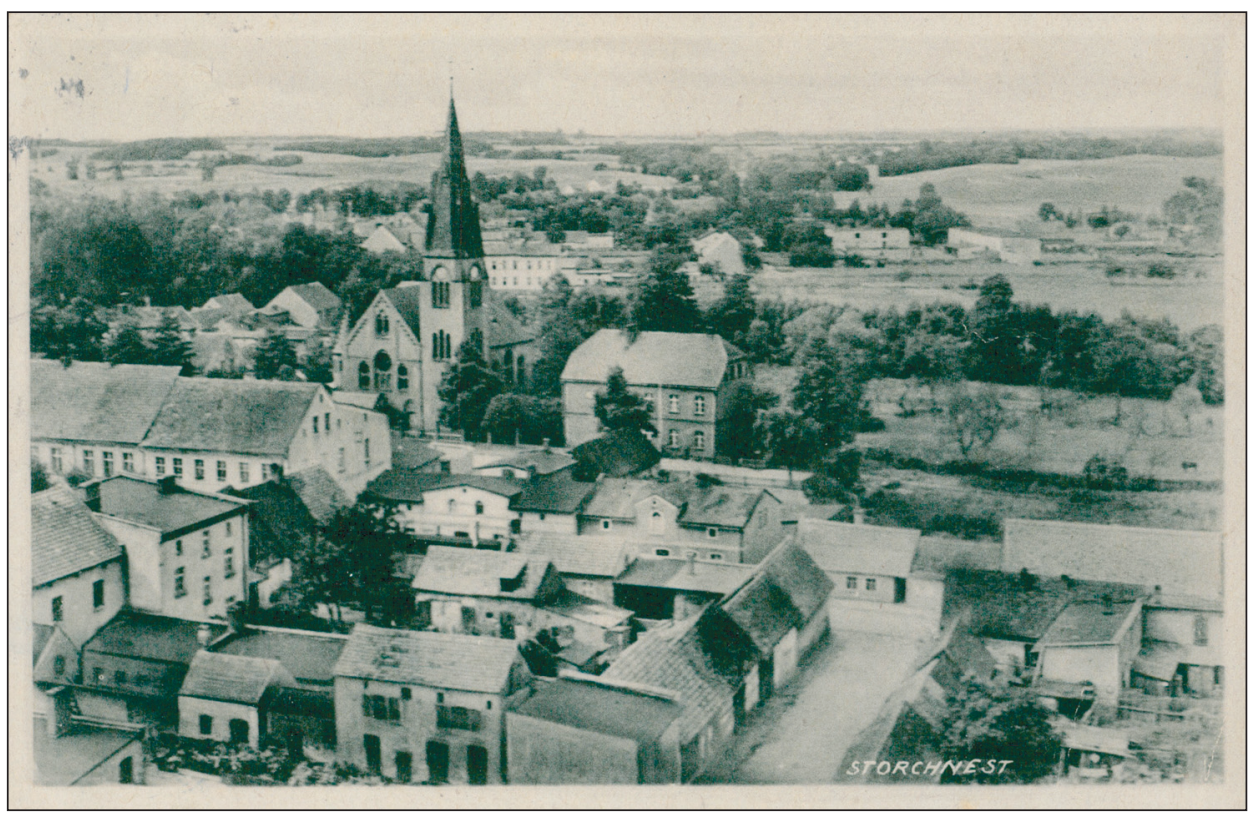

Ryc. 1. Nieistniejący obecnie kościół ewangelicki w Osiecznej oraz dawna szkoła ewangelicka (z prawej). Pocztówka, okres II wojny światowej (źródło: domena publiczna, polona.pl)

Fig. 1. The now-defunct Evangelical church in Osieczna and the former Evangelical school (on the right). Postcard, the period of World War II (source: public domain, polona.pl)

Nie sposób przedstawić historii świątyni i mienia byłej parafii bez wskazania aktów prawnych wydawanych od roku 1945 przez władze polskie. Regulowały one sprawy organizacyjne, majątkowe i personalne funkcjonujących oraz opuszczonych pod koniec wojny parafii protestanckich. Wśród licznych rozporządzeń, dekretów i ustaw dotyczących mienia porzuconego (poniemieckiego) i Kościołów protestanckich ${ }^{9}$, można wymienić najważniejsze z nich, dotyczące prezentowanego zagadnienia: Dekret z dnia 2 marca 1945 r. o majątkach opuszczonych i porzuconych, Ustawa z dnia 6 maja 1945 r. o majatkach opuszczonych i porzuconych, Dekret $z$ dnia 8 marca 1946 r. o majątkach opuszczonych i poniemieckich, Dekret z dnia 19 września 1946 r. o zmianie dekretu Prezydenta Rzeczypospolitej z dnia 25 listopada 1936 r. o stosunku Państwa do Kościoła Ewangelicko-Augsburskiego w Rzeczypospolitej Polskiej oraz Ustawa z dnia 4 lipca 1947 r. o zmianie dekretu Prezydenta Rzeczypospolitej z dnia 25 listopada 1936 r. o stosunku Państwa do Kościoła Ewangelicko-Augsburskiego w Rzeczypospolitej Polskiej. Na mocy dekretu i ustawy z 1945 r. powołany został Główny Urząd Tymczasowego Zarządu Państwowego (przy Ministerstwie Skarbu) dla majątków opuszczonych i porzuconych (art. 5 dekretu i ustawy). Umożliwiło to władzom lokalnym objęcie majątku poniemieckiego (w tym poewangelickiego) zarządem tymczasowym. Ustawa odebrała też parafiom prawo do ziem uprawnych, które zostały przekazane władzom rolnym (art. 15) ${ }^{10}$. Na mocy dekretu z 8 marca 1946 r. powołano do istnienia Główny Urząd Likwidacyjny z podległymi mu urzędami okręgowymi. Ich zadaniem było: zabezpieczenie majątków opuszczonych do chwili przejęcia przez właściwe dla danego majątku władze, kontrola i sporządzanie ich inwentarzy, oddawanie ich

\footnotetext{
9 Więcej na temat aktów prawnych, zob.: Sławiński W. 2009, s. 356-358.

${ }^{10}$ Dekret 1. 1945; Ustawa 1. 1945; Sławiński W. 2009, s. 363.
} 
w najem lub dzierżawę, dokonanie czynności prawnych względem majątków przechodzących na własność Skarbu Państwa oraz sprzedaż tych niszczonych, a zarazem drogich w utrzymaniu (art. 7, ust. 1-3). Urząd podlegał Prezesowi Rady Ministrów, a na tzw. Ziemiach Odzyskanych — Ministrowi Ziem Odzyskanych ${ }^{11}$. Na mocy dekretu z 19 września 1946 r. i późniejszej ustawy z 4 lipca 1947 r. ${ }^{12}$ do Kościoła Ewangelicko-Augsburskiego (dalej cyt.: KEA), którego zasięg objął terytorium całego kraju (w tym tzw. Ziemie Odzyskane), włączono byłe parafie i wiernych Kościołów ewangelicko-unijnych (Pomorze, Wielkopolska, Górny Śląsk), Staroluterskiego, Ewangelickiego Kościoła Augsburskiego i Helweckiego Wyznania oraz Braci Morawskich (Hernhuci). W ten sposób praktycznie zlikwidowano powyższe Kościoły poprzez wcielenie ich parafii i wiernych do ogólnopolskiego KEA (art. 1). Ich mienie, które nie było w posiadaniu KEA w dniu 31 października 1946 r. (wejście w życie dekretu z 19 września 1946 r.), przechodziło na własność Skarbu Państwa. Natomiast dobra będące w posiadaniu KEA (na dzień 31 października 1946 r.) pozostawały własnością kościelną. W ten sposób pozbawiono dotychczasowych właścicieli (różne Kościoły ewangelickie) mienia, bowiem dobra zajmowane przez KEA były już wtedy (jesienią roku 1946) nieliczne w stosunku do posiadłości sprzed $1945 \mathrm{r}$. Przejęty przez państwo majątek Rada Ministrów mogła zgodnie z prawem przyznać w części lub w całości na własność lub w zarząd instytucjom prawa publicznego i związkom wyznaniowym, z uwzględnieniem pierwszeństwa polskich ewangelików (art. 2). Artykułem 3 ustawy uchylono wcześniejsze akty prawne (od XIX w.) dotyczące kwestii prawno-organizacyjnych poszczególnych Kościołów ${ }^{13}$. Uchwalenie dekretu i późniejszej ustawy umożliwiło zarządom miejskim podjęcie starań o przejęcie na własność lub w użytkowanie administrowanego dotychczas (zarząd tymczasowy) majątku poewangelickiego.

Pierwszy znany ze źródeł spis zdawczo-odbiorczy osieckiego mienia porzuconego (w tym poewangelickiego) został sporządzony przez Zarząd Miejski Osiecznej 27 marca 1946 r. Od tego dnia nieruchomości te oficjalnie były administrowane przez władze miejskie Osiecznej ${ }^{14}$. Materiały archiwalne nie precyzują, kto był osobą za to odpowiedzialną od momentu zakończenia okupacji niemieckiej do 27 marca 1946 r. Wcześniejszy (po 27 stycznia 1945 r.) zarząd dobrami poniemieckimi odbywał się zapewne na podstawie przepisów zawartych w dekrecie z 2 marca 1945 r. o majątkach porzuconych. Brak informacji w źródłach i literaturze nie pozwala wskazać konkretnej osoby, która zarządzała tymi dobrami. Z pewnością władze lokalne nie były obojętne na kwestię pozostawionego majątku i zajmowały się także tą sprawą (ktoś ich doglądał, nimi zarządzał). Nie wiadomo jednak, w jaki sposób i przez kogo to czyniono.

Kolejny spis nieruchomości poniemieckich został przeprowadzony 24 maja 1948 r. Sporządzono go po posiedzeniu Miejskiej Rady Narodowej miasta Osieczna (22 maja). Rada podjęła wówczas uchwałę (9 za, 4 wstrzymało się, 3 nieobecnych) o wszczęciu postępowania w sprawie przyznania miastu na własność nieruchomości poniemieckich, należących niegdyś do Ewangelickiej Gminy kościelnej w Osiecznej ${ }^{15}$. Sprawę następnie przekazano Okręgowemu Urzędowi Likwidacyjnemu w Poznaniu (24 maja 1948 r.), wnioskując o przyznanie nieruchomości (w tym gruntów) po byłej parafii ewangelicko-unijnej w Osiecznej. W czerwcu do Urzędu Wojewódzkiego w Poznaniu wpłynęła zgoda seniora diecezji wielkopolskiej Kościoła Ewangelicko-Augsburskiego na przekazanie Zarządowi Miejskiemu z Osiecznej lub Polskiemu Narodowemu Kościołowi Katolickiemu nieruchomości byłej osieckiej parafii unijnej, o ile nie ma na tym terenie ewangelików. Odpowiedź poznańskiego urzędu (7 lipca 1948 r.) na wniosek

11 Dekret 2. 1946.

12 Więcej na temat procesu tworzenia ustawy, zob.: Zieliński T.J. 2009, s. 341-355.

13 Dekret 3. 1946; Ustawa 2. 1947.

${ }^{14}$ AP Leszno, AO, sygn. 702, s. 30-35.

15 AP Leszno, AO, sygn. 702, s. 46-47. 
osieckiego Zarządu z 24 maja br. odesłała wnioskodawców do właściwego w tej kwestii organu państwowego (zgodnego z ustawą z 4 lipca 1947 r.), czyli (formalnie) do Rady Ministrów, za pośrednictwem Ministerstwa Administracji Publicznej (faktycznie rozstrzygało ono kwestie majątków i wydawało decyzje) ${ }^{16}$. Administracyjną pomyłkę Zarządu Miejskiego z Osiecznej skorygowano, a 21 sierpnia 1948 r. za pośrednictwem Starostwa Powiatowego w Lesznie wystosowano do Ministerstwa pierwsze pismo w powyższej kwestii. Zarząd, powołując się na ustawę z 4 lipca 1947 r., wnioskował o przyznanie miastu całego mienia byłej gminy ewangelickiej w Osiecznej (czyli świątyni, domu pastora, domu towarzystw niemieckich, domu dla ubogich i gruntów rolnych). Wniosek umotywowano brakiem w mieście odpowiednich lokali na urządzenie Ośrodka Zdrowia, Stacji Opieki nad Matką i Dzieckiem oraz Domu Ludowego, a także brakiem roli szkolnej. Zabudowania parafii protestanckiej ze względu na ich lokalizację i stan zachowania dobrze nadawały się do takich celów. Przejęcie nieruchomości przyczyniłoby się — w ocenie wnioskodawcy pisma z 21 sierpnia 1948 r. — do rozwoju społeczno-kulturalnego i zdrowotnego miasta ${ }^{17}$. Ponowne pismo w tej sprawie (bardziej szczegółowe w opisie nieruchomości i ruchomości byłej gminy wyznaniowej) wysłano do Ministerstwa 28 stycznia 1949 r. Plan ewentualnego zagospodarowania dóbr poewangelickich pozostawiono prawie niezmieniony (jak w piśmie z 21 sierpnia 1948 r.). Podano jedynie inną (mniejszą) wielkość roli parafialnej (19,36 ha) oraz zamysł zagospodarowania świątyni. Miała stać się salą zebrań i przedstawień ${ }^{18}$. Urząd Wojewódzki w Poznaniu w piśmie z 7 marca 1949 r. skierowanym do Ministerstwa Administracji Publicznej poparł wniosek Zarządu Miejskiego z Osiecznej ${ }^{19}$. Dnia 7 czerwca 1949 r. Zarząd Miejski w Osiecznej wysłał zapytanie do Ministerstwa w sprawie odpowiedzi na pismo Zarządu ze stycznia bieżącego roku²0. Ministerstwo w odpowiedzi z 7 lipca 1949 r. poinformowało, że ,podanie do Ministerstwa nie wpłynęło"21. W zachowanych dokumentach brak ponownego (trzeciego już) listu, który zostałby wysłany do Ministerstwa przez ten Zarząd. Dokument musiał odnaleźć się w Ministerstwie lub przesłano jego kopię, gdyż odnosząc się do niego przyznano miastu mienie poewangelickie. Świadczy o tym akt zdawczo-odbiorczy z 10 stycznia 1950 r., dotyczący nieruchomości po opisywanej gminie. Wynika z niego, że Ministerstwo już 19 kwietnia 1949 r. podjęło decyzję o przekazaniu w zarząd i użytkowanie Zarządowi Miejskiemu z Osiecznej nieruchomości byłej parafii ewangelicko-unijnej (bez części ziemi rolnej). Świątynię z prawem przebudowy przekazano Zarządowi na cele społeczne ${ }^{22}$. Dnia 4 marca 1950 r. Miejska Rada Narodowa w Osiecznej podjęła uchwałę o przejęciu wyżej wymienionych dóbr. Uchwała ta została potem zatwierdzona przez Prezydium Powiatowej Rady Narodowej w Lesznie ${ }^{23}$. W ten sposób majątek nieruchomy poewangelicki, uprzednio upaństwowiony, oddany został w zarząd i użytkowanie Zarządowi Miejskiemu miasta Osieczna. Wcześniejsze, religijne przeznaczenie, w powojennej rzeczywistości zmieniono na cele świeckie - społeczne i gospodarcze.

Przynajmniej do wiosny 1950 r. świątynia nie była użytkowana i pozostawała zamknięta. W mieście i okolicy nie było bowiem ani ludności ewangelickiej pochodzenia polskiego, ani ludności polsko-katolickiej, której mogłaby ona służyć do celów kultu religijnego ${ }^{24}$. W związku z powyższym niezrozumiałe wydają się starania władz Polskiego Narodowego Kościoła

${ }^{16}$ AP Leszno, AO, sygn. 702, s. 40; IPN Poznań, UWP, sygn. 19/15, s. 265.

${ }^{17}$ AP Leszno, AO, sygn. 702, s. 41.

18 AP Leszno, AO, sygn. 702, s. 45.

19 IPN Poznań, UWP, sygn.19/15, s. 267.

${ }^{20}$ AP Leszno, AO, sygn. 702, s. 61.

${ }^{21}$ AP Leszno, AO, sygn. 702, s. 62.

${ }^{22}$ AP Leszno, AO, sygn. 702, s. 67.

${ }^{23}$ AP Leszno, AO, sygn. 702, s. 70.

${ }^{24}$ AP Leszno, AO, sygn. 702, s. 45. 
Katolickiego, który zabiegał o ,przekazanie mu zboru poewangelickiego wraz z przynależnymi nieruchomościami" 25 . Prośba taka została wystosowana do Ministerstwa Administracji Publicznej przez biskupa Józefa Padewskiego, ordynariusza tej instytucji. Została jednak oddalona przez władze powiatowe, ze względu na brak wyznawców tego Kościoła zarówno w Osiecznej, jak i okolicznych wsiach ${ }^{26}$.

Ostatecznie budynek - wbrew decyzji Ministerstwa o przekazaniu go cele społeczne — stał się magazynem zbożowym miejscowej, Gminnej Spółdzielni „Samopomoc Chłopska”27 i nieformalnym miejscem zabaw dzieci, które z empor skakały w zboże wysypane wprost na posadzce $^{28}$. Los osieckiej świątyni wpisywał się tym samym w sposób zagospodarowania tego typu obiektów realizowany na obszarze województwa poznańskiego i innych regionów kraju ${ }^{29}$.

Plan Ogólny Zagospodarowania Przestrzennego Osiecznej z 1963 r. potwierdza, iż w tym czasie budynek świątyni pełnił funkcje magazynowe. Składowano w nim m.in. zboże. Jego powierzchnia wynosiła $467 \mathrm{~m}^{2}$. Zatrudnionych było tu dwóch pracowników. Jednym z nich był pan Szpurek, mieszkaniec Osiecznej. Do 1963 r. dawny kościół nie został właściwie (w ocenie władz) przystosowany do pełnienia funkcji gospodarczych. Adaptację taką pod nadzorem Wojewódzkiego Konserwatora Zabytków w Poznaniu planowano przeprowadzić w przyszłości. W latach 1966-1970 zamierzano wybudować w innym miejscu (w pobliskiej miejscowości Kąkolewo) mieszalnie pasz i nowy spichlerz zbożowy spółdzielni. Niewątpliwie miało to na celu odciążenie obiektu osieckiego, ale prawdopodobnie także pozbawienie go racji dalszego funkcjonowania ${ }^{30}$.

Dnia 14 października 1970 r. prezes Powiatowego Związku Gminnych Spółdzielni (dalej cyt.: PZGS) „Samopomoc Chłopska” w Lesznie, Kazimierz Krawiec, wystosował do Prezydium Powiatowej Rady Narodowej w Lesznie pismo z sugestią (podjętą uprzednio 6 października tego roku przez zarząd PZGS) zmiany sposobu użytkowania byłego kościoła ewangelickiego w Osiecznej. Proponował wykupienie go od władz miejskich za sumę (maksymalnie) 100000 zł, a następnie zaadaptowanie na rozlewnię piwa i wód gazowanych. Miało to rozwiązać problemy gmin Osieczna i Lipno z zaopatrzeniem w napoje chłodzące. Inwestycję przewidywano w latach 1971-197231. Jesienią 1970 r. omawiany magazyn zbożowy — świątynia nadal funkcjonował. Obiekt miał cechy sakralne i w ocenie Prezydium Miejskiego Powiatowej Rady Narodowej w Lesznie winien je zatracić. Polecenie takie otrzymał wspomniany powyżej prezes PZGS, Kazimierz Krawiec. Poinformowano go również, iż funkcjonowanie budowli jako spichlerza będzie kontynuowane ${ }^{32}$. Plan prezesa został odrzucony.

Jeszcze na przełomie lat sześćdziesiątych i siedemdziesiątych XX w. świątynia była w dobrym stanie. Stanowiła jedną z dominant miejskiego krajobrazu. Strzelista wieża i boczne wieżyczki, zachowane w oknach witraże i neogotycka ceglana konstrukcja miały nadawać ul. Szkolnej (dawniej ul. Łaziebna) swoistego piękna. Kościół został wybudowany na podwyższeniu. Do wejścia znajdującego się od wschodu prowadziło kilka stopni. Od zachodu obiekt

25 AP Leszno, SPL, sygn. 70, s. 8.

${ }^{26}$ IPN Poznań, UWP, sygn. 19/15, s. 262; AP Leszno, SPL, sygn. 70, s. 8; AP Leszno, AO, sygn. 702 , s. 36.

${ }^{27}$ Gminna Spółdzielnia „Samopomoc Chłopska” (dalej cyt.: GS Osieczna) powstała w maju 1945 r., a funkcjonowanie rozpoczęła 09.07.1945 r. Prowadziła działalność usługowo-handlową (sklepy, parki maszyn rolniczych, usługi dla rolników, np. orka). Poza tym zarządzała magazynami zboża i nawozów sztucznych, masarniami, młockarniami, krochmalniami. GS Osieczna funkcjonuje do dziś (2019), Jędraś S. 2012, s. 156-157.

${ }^{28}$ Nowak L. 2016.

29 Małyszka A. 2004.

30 AP Leszno, WBPPL, sygn. 297, s. 23; Juchniewicz J. 2016.

31 AP Leszno, PMRNOS, sygn. 171, s. 80.

32 APL, PMRNOS, sygn. 171, s. 83. 
był podpiwniczony. Piwnicę tę GS Osieczna wykorzystywała jako miejsce skupu oraz przechowalnię warzyw i owoców ${ }^{33}$.

Pomimo planów dalszego użytkowania budowli jako magazyn została ona rozebrana. Według Macieja Michalskiego miało to miejsce w 1975 r. ${ }^{34}$ Rozbiórkę prowadzono tak, aby odzyskać jak najwięcej cegieł, które zamierzano użyć do budowy wspomnianej mieszalni pasz w Kąkolewie ${ }^{35}$. Część budulca uległo jednak zniszczeniu, gdyż łącząca je zaprawa była trwałym spoiwem. Do prac tych zaangażowano członków osieckiego zespołu piłkarskiego (pracowali w niedziele do południa), którym w zamian obiecano transport na mecze piłkarskie. Rozbiórkę obiektu nadzorowały służby porządkowe, w tym ubrani po cywilnemu funkcjonariusze leszczyńskiej Służby Bezpieczeństwa. Pilnowali, aby podczas demontażu świątyni nie wykonywano żadnych fotografii. Według Józefa Juchniewicza, funkcjonariusze SB przeszukali dom jednego z mieszkańców, który zrobił takie zdjęcia. Znalezione materiały zarekwirowano, a rodzina miała $\mathrm{z}$ tego powodu „pewne nieprzyjemności”. Z relacji wynika, że rozbiórkę rozpoczęto od zrzucenia hełmu wieży kościelnej przy pomocy lin przyczepionych do traktora. Następnie nacięto mur wieży i przewrócono go przy użyciu dwóch traktorów. Dalsze prace prowadzono ręcznie ${ }^{36}$.

Do dziś zachowały się cztery fotografie dokumentujące tamte wydarzenia - ukazujące moment destrukcji wieży. Wykonano je z budynku (przypuszczalnie z pierwszego piętra) stojącego przy obecnej ul. Kościuszki, czyli na wprost ul. Szkolnej. Autor zdjęć jest nieznany ${ }^{37}$.

Jeszcze jakiś czas po rozbiórce, na placu, na którym niedawno stała świątynia, leżały stosy ułożonych cegieł. W ocenie mieszkańców ulica straciła swój urok, a miasto zabytek. Wielu mieszkańców w prywatnych i nieoficjalnych rozmowach krytykowało, i czyni to do dziś, decyzję o zniszczeniu kościoła. Żałowali utraty „,pięknego obiektu”, który był elementem otaczającej ich rzeczywistości i upiększał panoramę miasteczka ${ }^{38}$.

Dokładnie nie wiadomo, dlaczego dokonano rozbiórki. Dotychczas nie odnaleziono dokumentu zawierającego postanowienie w tej sprawie. Najprawdopodobniej miało to związek z ówczesnymi decyzjami politycznymi i podyktowane było względami ekonomicznymi. Sugeruje to dokument z Urzędu Wojewódzkiego w Poznaniu wydany 25 czerwca 1970 r. Podjęto wówczas uchwałę o rozbiórce nieużywanych obiektów poewangelickich lub ich zagospodarowaniu w połączeniu z pozbawieniem cech sakralnych. Decyzja dotyczyła całego województwa poznańskiego. Do rozbiórki wytypowano 25 obiektów. Zarządzenie motywowano działaniami Kościoła katolickiego, który był zainteresowany określonymi zabudowaniami. Wyrażano obawę, iż posłużą one do powstania nowych parafii lub filii już istniejących. Był to zatem element walki z instytucją Kościoła katolickiego.

Nie dotyczyło to jednak Osiecznej. Były tam bowiem dwa kościoły katolickie (parafialny i klasztorny) oraz kaplica ss. Elżbietanek, którą także udostępniano wiernym. Świątynię rozebrano prawdopodobnie z powodu rezygnacji PZGS Leszno z wcześniejszych planów jej przebudowy (modernizacji, desakralizacji), co mogło być zbyt kosztownym przedsięwzięciem ${ }^{39}$. Ponadto w Kąkolewie wznoszono już (ok. 1975 r.) nowoczesną mieszalnię pasz ${ }^{40}$.

Po 1989 r. powróciła kwestia własności (rewindykacja) mienia Kościołów protestanckich funkcjonujących w drugiej Rzeczpospolitej. Sprawy związane z dobrami Kościołów wymienionych w ustawie z 4 lipca 1947 r. oraz Kościoła Ewangelicko-Augsburskiego w Polsce objęła

33 Nowak B. 2016.

34 Michalski M. 2005, s. 49.

35 Nowak L. 2016.

36 Juchniewicz J. 2016.

37 Michalski M. 2005, s. 54.

38 Nowak B. 2016.

39 IPN Poznań, UWP, sygn. 19/25, s. 249, 262-264, 298-299.

40 Jędraś S. 2012, s. 158. 
ustawa z 13 maja 1994 r. „o stosunku Państwa do Kościoła Ewangelicko-Augsburskiego w Rzeczypospolitej Polskiej”" ${ }^{4}$. KEA został uznany za prawnego sukcesora Kościołów wcielonych do niego na mocy ustawy z 4 lipca 1947 r. Na tej podstawie mógł przejąć na własność aktualnie użytkowane nieruchomości. Ma także możliwość dochodzenia praw majątkowych na drodze postępowań administracyjnego, regulacyjnego i sądowego odnośnie do obiektów znacjonalizowanych po wojnie i będących obecnie własnością osób prawnych państwowych. Pięć lat opóźnienia (1989-1994) w uchwaleniu ustawy umożliwiło Skarbowi Państwa przekazanie mienia poewangelickiego samorządom, zaś samorządom — na jego zagospodarowanie (nierzadko kontynuowanie dotychczasowej działalności społecznej lub mieszkaniowej) lub sprzedaż osobom prywatnym. Według D. Binemann-Zdanowicza, roszczenia majątkowe wysuwane przez KEA miały być ograniczone (tzw. samoograniczenie Kościoła) do określonych nieruchomości lub gruntów (głównie niezabudowanych), aby nie nadwyrężać możliwości samorządów i lokalnych społeczności, oraz nie stwarzać okazji do ataku na „zachłanny Kościół”42. W rzeczywistości proces ten przebiegał różnie. $Z$ jednej strony trudno nie zgodzić się z twierdzeniem, iż własność odebrana powinna być zwrócona. Z drugiej zaś lokalne samorządy niewątpliwie stanęły przed niełatwym do realizacji problemem rewindykacji, utraty nieruchomości lub zapłaty za nie.

W przypadku regionu leszczyńskiego (przedwojenna superintendentura Leszno) na przełomie XX i XXI w. poznańska parafia ewangelicko-augsburska pod przewodnictwem księdza Tadeusza Raszyka (1948-2012) podjęła szereg działań rewindykacyjnych w stosunku do nieruchomości i terenów niezabudowanych, należących przed rokiem 1945 do byłych parafii ewangelicko-unijnych. Prasa lokalna donosi, iż starania te - przeważnie zakończone zwrotem, zamianą terenów lub wypłatą ekwiwalentu — były procesem długotrwałym i skomplikowanym dla obu stron. W relacjach zaznacza się jednak otwartość Kościoła na różne propozycje rozwiązania tego problemu ${ }^{43}$.

Obecnie teren dawnego kościoła w Osiecznej jest własnością prywatną. Na jej części, obok miejsca lokalizacji świątyni, wzniesiono dom jednorodzinny, w którym w latach dziewięćdziesiątych XX w. mieścił się pub. Pozostała część — z widocznymi na powierzchni śladami fundamentów kościoła — służy jako prywatny ogród (trawnik) rekreacyjny ${ }^{44}$.

\section{Dom pastora, szpital-przytułek, dom towarzystw niemieckich}

Niesakralne budynki poewangelickie z Osiecznej po zakończeniu drugiej wojny światowej również zostały przejęte w tymczasową administrację przez władze miasta. Do momentu ostatecznego rozstrzygnięcia kwestii własnościowej zarządcą i użytkownikiem byli Edmund Skrobała i Marcin Kraśner ${ }^{45}$.

Dom pastora (obecnie przy ul. Szkolnej 2), w przypadku przyznania go miastu przez Ministerstwo Administracji Publicznej, lokalne władze planowały przeznaczyć na Ośrodek Zdrowia oraz Punkt Opieki nad Matką i Dzieckiem. Miasto nie posiadało bowiem własnych budynków w ten cel, a obiekty byłej parafii wydawały się odpowiednie ze względu na ich dobry stan techniczny i położenie w pobliżu centrum. Decyzją z 19 kwietnia 1949 r. Ministerstwo przekazało dom pastora wraz z zabudowaniami gospodarczymi Zarządowi Miejskiemu w Osiecznej oraz udzieliło pozwolenia na ich przebudowę i dostosowanie do celów społecznych. Punkt

41 Ustawa 3. 1994.

42 Binemann-Zdanowicz D. 2009, s. 372-400.

43 Juchniewicz J. 2016; https://leszno.naszemiasto.pl/ewangelicy-chca-zboru-i-pastorowki/ar/c8-5251829 (dostęp 08.10.2019); https://leszno.naszemiasto.pl/ewangelikom-co-ewangelickie/ar/c8-5725021 (dostęp 08.10.2019); https://leszno.naszemiasto.pl/bojanowo-zachowa-przedszkole/ar/c1-5313903 (dostęp 08.10.2019).

${ }^{44}$ Na podstawie: Wizja lokalna. 2019.

45 AP Leszno, AO, sygn. 702, s. 27. 
Opieki nad Matką i Dzieckiem oraz Stacja Opieki nad Matką i Dzieckiem zostały jednak już wcześniej (w 1946 r.) ulokowane w Zakładzie św. Józefa ${ }^{46}$ przy ul. Leszczyńskiej 90a (dziś ul. Kościuszki 18). Był on własnością Zgromadzenia Sióstr św. Elżbiety. Uruchomiono tam również Ośrodek Zdrowia, który pozostał w nim do początku drugiej dekady XXI w. Siostry elżbietanki opuściły Osiecznę w roku 2013, sprzedawszy wszystkie tamtejsze nieruchomości. W archiwaliach brak danych co do przyczyny rezygnacji z pierwotnych zamierzeń zagospodarowania opisywanego budynku ${ }^{47}$.

Opisywany obiekt jest murowany, obecnie (odnośnie do jego dawnego wyglądu brak informacji) otynkowany i podpiwniczony, w układzie kalenicowym. Składa się z jednej kondygnacji i poddasza (strych), przykryty jest dwuspadowym dachem. Główne wejście, znajdujące się od strony ul. Szkolnej, poprzedza niewielka weranda i kilka schodów ${ }^{48}$. Według Barbary Nowak, weranda jeszcze do początku lat siedemdziesiątych XX w. była obudowana kolorowymi szybami, co miało dodawać jej „uroku”49.

Szczegółowe losy obiektu od momentu upaństwowienia (w 1949 r.), a także przejęcia w zarząd i użytkowanie przez miasto (w 1950 r.) są nieznane (brak wzmianek w źródłach). Wiadomo, iż — podobnie jak współcześnie — pełnił on funkcje mieszkalne ${ }^{50}$.

Szpital dla ubogich wyznania ewangelickiego w Osiecznej od 1897 r. znajdował się przy ówczesnej ul. Leszczyńskiej 54 (dzisiejszej ul. Kościuszki). Według danych z 26 lipca 1922 r. w szpitalu-przytułku przebywało wówczas osiem osób w starszym wieku. Placówka nie zatrudniała personelu. Kierował nią każdy z osieckich pastorów ${ }^{51}$. Budynek był domem parterowym, o spadzistym dachu pokrytym dachówką. Obok na podwórzu stał jeden chlew (lepianka). Powierzchnia działki wynosiła 0,03 ha. Od 27 marca 1946 r. obiekt był administrowany przez Zarząd Miejski ${ }^{52}$, który planował urządzić w nim dom dla ubogich mieszkańców miasta, aby zachować jego dotychczasową funkcję ${ }^{53}$. Decyzją Ministerstwa Administracji Publicznej z 19 kwietnia 1949 r. Zarząd otrzymał dawny szpital-przytułek z przeznaczeniem na cele społeczne ${ }^{54}$. Ostatecznie oddano go jednak do zamieszkania. W ten sposób zaniechano lokalnej tradycji protestanckiego szpitalnictwa i działalności opiekuńczej, zaś pamięć o nich uległa zatarciu.

Kolejną nieruchomość byłej parafii stanowił dom towarzystw niemieckich, usytuowany pod numerem 103 przy ówczesnej ul. Łaziebnej (dziś ul. Szkolna 1). Do momentu przyznania go miastu Osieczna przez Ministerstwo Administracji Publicznej (19 kwietnia 1949 r.) znajdował się pod tymczasowym zarządem państwowym. Na pewno w roku 1947 mieściła się w nim siedziba Polskiej Partii Robotniczej Koło Osieczna ${ }^{55}$. Data rozpoczęcia i zakończenia użytkowania budynku przez tę organizację nie jest znana. Pomiędzy 1945 a 1947 rokiem (nie wiadomo jak długo, gdyż brak dat na dokumencie) osobą zarządzającą nieruchomością był Edmund Skrobała ${ }^{56}$.

${ }^{46}$ Funkcjonował on w latach 1905-1940. Był to dom opieki dla upośledzonych umysłowo kobiet. Prowadziły go ss. Elżbietanki. 25.02.1940 r. pensjonariuszki zostały wywiezione i zgładzone przez niemieckiego okupanta. Kilka miesięcy później siostry opuściły Osiecznę, zaś obiekt przeznaczono na dom partii (Parthaus), Frankiewicz E. 1986, s. 97-98, 196, 297-299.

47 AP Leszno, AO, sygn. 702, s. 45; AP Leszno, AO, sygn. 665, b. pag. http://elka.pl/content/view/65945/80/ (dostęp 10.04.2019).

${ }^{48}$ Na podstawie: Wizja lokalna. 2019.

49 Nowak B. 2016.

50 Juchniewicz J. 2016.

51 AP Leszno, SPL, sygn. 539, s. 38.

52 AP Leszno, AO, sygn. 683, s. 1-9.

53 AP Leszno, AO, sygn. 702, s. 41.

54 AP Leszno, AO, sygn. 702, s. 67.

55 AP Leszno, AO, sygn. 588, b. pag.

56 AP Leszno, AO, sygn. 588, b. pag. 
Od roku 1948 jako zarządca (powiernik) ustanowiony przez Powiatowy Urząd Ziemski w Lesznie widnieje w aktach Marcin Kraśner ${ }^{57}$. Był on członkiem miejscowej PPR. Można zatem przypuszczać, iż budynek potem wciąż służył partii, a przynajmniej jej działaczowi. Po ewentualnym przyznaniu obiektu władzom miasta zamierzano przeznaczyć go na dom ludowy dla organizacji i partii politycznych, co byłoby kontynuacją stanu aktualnego. Decyzją Ministerstwa Administracji Publicznej z 19 kwietnia 1949 r. dom ten przyznano miastu z przeznaczeniem na „miejskie cele społeczne" ${ }^{58}$. Dalsze losy obiektu są nieznane (brak źródeł). Obecnie pełni funkcje mieszkalne.

\section{Własność ziemska}

Osiecka gmina ewangelicka posiadała również majątek ziemski. Były nim tereny uprawne, łąki, ogrody i sad. Na przestrzeni kilku wieków wspólnota wyznaniowa nabywała je za zgodą właścicieli miejscowych dóbr, m.in. na mocy przywileju Adama Olbrachta Przyjemskiego (1590-1644) z 24 lutego 1635 r., który zezwalał na dokupienie ziemi pod zabudowania gminy wyznaniowej ${ }^{59}$. Zakupów takich dokonywali także późniejsi pastorzy; udokumentowane przykłady pochodzą z XIX i XX w. Pastor Albert Taube informuje, że w 1821 r. pastor Johann Martin Fechner nabył dla kościoła i gminy wyznaniowej okazałą działkę. Miała służyć utrzymaniu kaznodziei i wdów nauczycielek ${ }^{60}$. Z kolei w 1826 r. za 120 talarów zakupił część pola ornego Kasubskiego w podobnym celu - na utrzymanie kaznodziei, nauczycieli i wdów po kościelnych (zakrystianach) ${ }^{61}$. Proces nabywania innych działek i ich lokalizacja nie zostały, jak dotąd, szczegółowo zbadane. Powojenna nacjonalizacja mienia kościelnego poewangelickiego w Osiecznej i związana z nią inwentaryzacja dóbr pozwala jedynie poznać stan (wielkość w hektarach) gruntów należących do byłej osieckiej parafii ewangelicko-unijnej.

Według Wykazu nieruchomości poniemieckich nie będących w administracji samorzadowej, a którego związi samorządowe zamierzają nabyć, celem usprawnienia administracji samorzadowej na własność z 16 lutego 1948 r. własnością Ewangelickiej Gminy kościelnej było łącznie 20,14 ha $^{62}$. Identyczną powierzchnię wymieniono w wykazie nieruchomości porzuconych, sporządzonym 24 maja 1948 r. $^{63}$ oraz we wniosku Zarządu Miejskiego z Osiecznej do Ministerstwa Administracji Publicznej w Warszawie z dnia 21 sierpnia 1948 r. w sprawie o przyznanie nieruchomości parafialnych miastu. W następnym piśmie dotyczącym tej samej kwestii (do tego samego Ministerstwa) — z 28 stycznia 1949 r. podano mniejszy areał $(19,36 \text { ha })^{64}$, zaś jeszcze inną wielkość (19,94 ha) w dokumencie wystawionym 28 maja 1947 r. przez Starostwo Powiatowe z Leszna ${ }^{65}$. Skąd ta różnica? Nie sprecyzowano tego w analizowanych aktach. Być może powodem rozbieżności były braki w zachowanej dokumentacji i proces szybkiej, dość spontanicznej odbudowy polskiej administracji.

${ }^{57}$ Marcin Kraśner - ur. 23.10.1897 r. w Trzebini, pow. leszczyńskim, syn Jana i Franciszki Kraśnerów, powstaniec wielkopolski, szeregowiec mianowany na stopień podporucznika, rolnik zamieszkały w Osiecznej, członek PPR Koło Osieczna, przewodniczący Komisji Opieki Społecznej w Osiecznej (wybrany 23 czerwca 1945 r.), członek Miejskiej Komisji Budowlanej w Osiecznej (wybrany 8 lutego 1946 r.), zastępca przewodniczącego Miejskiej Komisji Kontroli Społecznej w Osiecznej, AP Leszno, AO, sygn. 571, b. pag. Uczestnicy powstania wielkopolskiego zob.: http://powstancywielkopolscy.pl/pl/ (dostęp 16.02.2019).

58 AP Leszno, AO, sygn. 702, s. 27, 67; AP Leszno, AO, sygn. 590, b. pag.

${ }^{59}$ Jędraś S. 2012, s. 51-52.

60 Taube A. 1899, s. 15.

61 Taube A. 1899, s. 30.

${ }^{62}$ AP Leszno, AO, sygn. 702, s. 27.

${ }^{63}$ AP Leszno, AO, sygn. 590, b. pag.

${ }^{64}$ AP Leszno, AO, sygn. 702, s. 45.

65 IPN Poznań, UWP, 19/15, s. 270. 
Własność ziemska parafii składała się łącznie z ogrodu owocowego i gospodarstwa rolnego z chlewem znajdujących się przy domu pastora (przy ówczesnej ul. Łaziebnej 104, dziś ul. Szkolnej 2) oraz łąk i ziem rolnych w pobliżu Osiecznej - przy drogach do Wojnowic, Świerczyny i na terenach graniczących z obrębem Drzeczkowo-Wołkowo ${ }^{66}$.

Zabiegi Zarządu Miejskiego w Osiecznej w sprawie przejęcia m.in. gruntów byłej parafii protestanckiej w Osiecznej trwały formalnie od 22 maja 1948 r. do wiosny 1950 r. Wcześniej, czyli od końca drugiej wojny światowej do momentu przejęcia ich przez miasto Osieczna (w 1950 r.), były użytkowane przez Marcina Kraśnera (wspomnianego powiernika Powiatowego Urzędu Ziemskiego w Lesznie) ${ }^{67}$. Uzyskane przez miasto ziemie zamierzano przeznaczyć „,częściowo na rolę szkolną, bowiem szkoła tut. nie posiada roli, a resztę na cele opieki społecznej" 68 .

Dnia 19 kwietnia 1949 r. Ministerstwo Administracji Publicznej podjęło decyzję m.in. o przekazaniu części upaństwowionych gruntów uprawnych (o powierzchni 13,62 ha) do Funduszu Ziemi, celem wykorzystania podczas planowanej reformy rolnej. Pozostałą część (ok. 6 ha) przyznano miastu Osieczna w zarząd i użytkowanie ${ }^{69}$. W następstwie decyzji o oddaniu gruntów Funduszowi, 9 lutego 1950 r. dotychczasowy ich użytkownik, rolnik Marcin Kraśner, zgłosił gotowość zdania całości gospodarstwa ${ }^{70}$. Niecały miesiąc później Referat Rolniczy Starostwa Powiatowego w Lesznie zwrócił się do Zarządu Miejskiego w Osiecznej z ponagleniem w sprawie podjęcia uchwały Miejskiej Rady Narodowej w Osiecznej o przekazaniu terenu do Funduszu Ziemi. Wezwanie umotywowano zbliżającą się akcją siewną, koniecznością

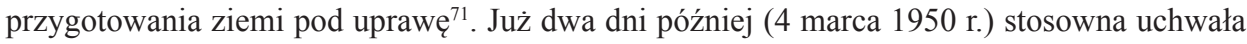
tutejszej Miejskiej Rady Narodowej została podjęta i następnie zatwierdzona przez Prezydium Powiatowej Rady Narodowej w Lesznie ${ }^{72}$. W ten sposób większa część gruntów byłej parafii ewangelickiej (tzn. 13,62 ha) trafiła do zarządu państwowego w ramach Funduszu Ziemi. Pozostałe oddano w użytkowanie miastu. Zachowane archiwalia nie zawierają danych odnośnie do dalszego zagospodarowania dóbr przez lokalny Zarząd Miejski. Własność parafii ewangelickiej, wcześniej będąca podstawą jej utrzymania, w powojennej rzeczywistości służyła polskiej katolickiej lub partyjnej społeczności Osiecznej i okolicy.

Czy przyznając dobra poniemieckie (zaborcy i okupanta) Polakom uznawano to za swoiste zadośćuczynienie lub sprawiedliwość dziejową? Czy może był to jedynie pragmatyzm, by w okresie powojennego niedostatku korzystać z porzuconego mienia? Z pewnością oba motywy miały wpływ na powojenne dzieje opisywanych dóbr.

\section{Mienie ruchome}

Trudne jest prześledzenie losów mienia ruchomego będącego własnością gmin ewangelickich. Stanowiło je wyposażenie świątyń oraz innych budynków parafialnych, takich jak plebanie, domy związkowe, szpitale, szkoły oraz zabudowania gospodarcze. Powodem jest deficyt źródeł, a także relacji świadków tamtych wydarzeń. To następstwo zniszczeń wojennych i szybkiej ewakuacji ludności niemieckiej (w tym parafii) przed zbliżającym się frontem, zimą $1945 \mathrm{r}$. Prawdopodobnie wraz z opuszczającymi miejscowość pastorami i członkami rad parafialnych

${ }^{66}$ AP Leszno, AO, sygn. 550, s. 17; AP Leszno, AO, sygn. 588, b. pag.; AP Leszno, AO, sygn. 702, s. $48-60$.

${ }^{67}$ AP Leszno, AO, sygn. 702, s. 27.

${ }^{68}$ AP Leszno, AO, sygn. 702, s. 41, 45.

${ }^{69}$ AP Leszno, AO, sygn. 702, s. 67.

${ }^{70}$ AP Leszno, AO, sygn. 702, s. 68.

${ }^{71}$ AP Leszno, AO, sygn. 702, s. 69.

72 AP Leszno, AO, sygn. 702, s. 70. 
ewakuowano najważniejsze (i zapewne najlżejsze) parafialne mobilia. Przedmioty, które pozostały w opuszczonych zabudowaniach, często stawało się łupem złodziei lub było przejmowane przez osoby prywatne bądź duchownych katolickich, celem dalszego ich użytkowania lub przechowania. Większe sprzęty (np. ławki, dzwony) były przenoszone do świątyń katolickich. Po wydarzeniach tych nie pozostała dokumentacja, gdyż z oczywistych względów (ewakuacja, rabunek) jej wtedy nie sporządzano.

Sytuacja unormowała się po roku 1945, gdy istniejące jeszcze samorządy, Urząd Likwidacyjny oraz władze Kościoła katolickiego w sposób bardziej sformalizowany zajęły się kwestią mienia byłych parafii protestanckich ${ }^{73}$. Powstałe wówczas akta dotyczą jednak przeważnie nieruchomości. Informacje o ważniejszych dobrach ruchomych (np. ławkach) przydatnych dla celów świeckich bądź kościelnych zawierają spisy sporządzane przez Okręgowe Urzędy Likwidacyjne, urzędy powiatowe i wojewódzkie oraz parafie starające się o przejęcie określonych ruchomości poewangelickich ${ }^{74}$.

Odnośnie do majątku ruchomego poewangelickiego z Osiecznej dysponujemy tylko źródłami pisanymi traktującymi o wyposażeniu świątyni, tj. o niektórych jej elementach. Natomiast nic nie wiadomo ani o rzeczach znajdujących się w domu pastora, ani w szpitalu-przytułku, domu towarzystw niemieckich, ani w budynkach o przeznaczeniu gospodarczym.

Jesienią 1946 r. do Zarządu Miejskiego w Osiecznej wpłynęło pismo od Komitetu Budowy Kościoła [katolickiego] w Czerwonaku koło Poznania. Komitet był zainteresowany przejęciem wyposażenia z poewangelickiej świątyni w Osiecznej. Lokalne władze porozumiały się z miejscowym proboszczem, księdzem Babskim, i na posiedzeniu 6 listopada 1946 r. dokonały analizy tych przedmiotów. W piśmie z 11 listopada 1946 r. poinformowały Starostwo Powiatowe w Lesznie o prośbie z Czerwonaku i o stanie świątyni. Wyposażenie kościoła było nieuszkodzone. Zarząd Miejski stwierdził, iż do Czerwonaku może przekazać: 4 ławki z lewej empory ( $8 \mathrm{~m}$ długości), ambonę, konfesjonał i kamienną chrzcielnicę. Zdecydowano, by ławki z nawy głównej pozostawić w budynku, gdyż w przypadku ich wyjęcia pozostałaby znaczna część wnętrza bez „flisów”; ławki stanowiły bowiem integralną element wnętrza świątyni. Argumentowano także, iż ławki będą przydatne dla planowanego w świątyni domu oświatowego, w którym miały odbywać się zebrania i koncerty. Zapewne pod wpływem księdza Babskiego Zarząd nie chciał wydać organów. Zamierzano przenieść je do jednego z osieckich kościołów katolickich, bowiem podczas działań wojennych zniszczeniu uległy organy w klasztorze, zaś te w farze zostały znacznie uszkodzone ${ }^{75}$. Starostwo Powiatowe przekazało sprawę wydziałowi Społeczno-Politycznemu Urzędu Wojewódzkiego w Poznaniu ${ }^{76}$. Z kolei Poznań poinformował o tym Departament Wyznaniowy Ministerstwa Administracji Publicznej i oczekiwał na jego ustosunkowanie się do podania Komitetu z Czerwonaka ${ }^{77}$. W tych samych dniach (18 listopada 1946 r.) Okręgowy Urząd Likwidacyjny z Poznania podjął decyzję o oddaniu poewangelickich organów z Osiecznej w dozór katolickiej parafii pw. św. Rocha w Poznaniu. Jednocześnie zezwolił na ich wywóz do Poznania. Postanowienie Urzędu było spowodowane wnioskiem poznańskiej parafii z 14 listopada 1946 r. ${ }^{78}$ Część organów została tam przekazana pomiędzy drugą połową listopada tegoż roku a pierwszą połową marca $1947 \mathrm{r}$. Pewne elementy instrumentu zatrzymano jednak w osieckiej parafii katolickiej. Urząd Wojewódzki Poznański prosił o ich oddanie do Poznania, zgodnie z decyzją Okręgowego Urzędu Likwidacyjnego ${ }^{79}$.

73 Birecki P. 2012, s. 685-690.

${ }^{74}$ Obserwacja na podstawie dokumentów archiwalnych wykorzystanych w poniższym tekście.

75 IPN Poznań, UWP, sygn. 19/15, s. 256.

76 IPN Poznań, UWP, sygn. 19/15, s. 255.

77 IPN Poznań, UWP, sygn. 19/15, s. 260.

78 IPN Poznań, UWP, sygn. 19/15, s. 257.

79 IPN Poznań, UWP, sygn. 19/15, s. 261. 
Efekt pisma nie jest znany. Prawdopodobnie owe części zostały wydane, gdyż w dokumentach brak dalszych ponagleń.

Pod koniec marca 1947 r. Ministerstwo Administracji Publicznej wystosowało do Urzędu Wojewódzkiego w Poznaniu pismo w sprawie majątku byłej osieckiej parafii ewangelickiej. Domagano się wyjaśnienia kwestii prawnych — własności dóbr poewangelickich z Osiecznej. Ponadto zaznaczono, iż Komitet Budowy Kościoła w Czerwonaku nie ma osobowości prawnej i tym samym nie może wnioskować o przyznanie mu jakiegokolwiek mienia ${ }^{80}$. Miesiąc później Starostwo Powiatowe w Lesznie przesłało do Urzędu Wojewódzkiego w Poznaniu odpowiednie pismo; w księgach wieczystych jako właściciel dóbr zapisana była osiecka parafia ewangelicka i Ewangelicka Parafialna Fundacja Ziemi dla Prowincji Poznańskiej ${ }^{81}$. Sprawa przekazania wnioskowanych ruchomości do Czerwonaku została ostatecznie rozstrzygnięta decyzją Ministerstwa Administracji Publicznej, wyrażoną pismem z 4 sierpnia $1947 \mathrm{r}$. Ministerstwo zawiadamiało Okręgowy Urząd Likwidacyjny w Poznaniu, iż nie widzi przeszkód w oddaniu urządzeń wewnętrznych osieckiej świątyni do Czerwonaku ${ }^{82}$. Akta nie precyzują, kiedy tego dokonano.

W skład analizowanego mienia ruchomego wchodził także dzwon kościelny. Po 1945 r. otrzymała go parafia katolicka z Osiecznej. Przetrwał wojnę, gdyż był wykonany ze stali, nieprzydatnej dla przemysłu zbrojeniowego. Dzwon służy miejscowym katolikom do dziś ${ }^{83}$.

W protokole zdawczo-odbiorczym z 10 stycznia 1950 r. stwierdzono, iż do kościoła poewangelickiego przejmowanego w zarząd i użytkowanie przez miejscowy Zarząd Miejski należały następujące mobilia: 25 ławek, 14 świeczników trójramiennych, 1 szafa żelazna starego typu oraz zegar ${ }^{84}$ wieżowy z czterema tarczami ${ }^{85}$. Nie wiadomo co stało się z ławkami, świecznikami oraz szafą po roku 1950. Z pewnością zostały usunięte z kościoła, gdy zrezygnowano z pomysłu przekształcenia go w salę kinową, zaś obiekt stał się magazynem GS Osieczna. Zegar przetrwał do czasu rozbiórki świątyni w latach siedemdziesiątych $\mathrm{XX} \mathrm{w} \cdot{ }^{86} \mathrm{Nie}$ wiadomo co dalej działo się z tymi rzeczami.

Losów innych parafialnych ruchomości nie wyjaśniono z powodu braku źródeł pisanych i relacji naocznych świadków.

\section{Podsumowanie}

Ewakuacja ludności niemieckiej zimą 1945 r. spowodowała kres działalności parafii ewangelicko-unijnej w Osiecznej. Jej majątek w późniejszych latach uległ nacjonalizacji i służył celom świeckim - społecznym i gospodarczym, co było działaniem typowym w takich przypadkach w powojennych realiach na ziemiach polskich. Względy ekonomiczne nie sprzyjały zachowaniu poewangelickiego dziedzictwa materialnego, o czym świadczy rozbiórka kościoła w połowie lat siedemdziesiątych XX w. Natomiast dzięki pełnieniu funkcji mieszkalnych inne nieruchomości przetrwały do dnia dzisiejszego i zachowały niezmieniony wygląd (na pewno z zewnątrz).

Powojenne losy omawianych dóbr mogły być inne, gdyby w mieście lub okolicy przebywało więcej ludności wyznania ewangelickiego. Według powojennego prawa (dekretu z $1946 \mathrm{r}$. i ustawy z 1947 r.) teoretycznie zachodziła możliwość dalszego użytkowania dóbr byłej gminy ewangelicko-unijnej na potrzeby kultu religijnego, przetrwania parafii lub powołania filii np.

${ }^{80}$ IPN Poznań, UWP, sygn. 19/15, s. 269.

81 IPN Poznań, UWP, sygn. 19/15, s. 270.

${ }^{82}$ IPN Poznań, UWP, sygn. 19/15, s. 273.

83 Łuczak T. 2008, s. 39.

${ }^{84}$ Dar Tassilo von Heydebrandta u.d. Lasa ofiarowany przed 1899 r., Taube A. 1899, s. 31.

${ }^{85}$ AP Leszno, AO, sygn. 702, s. 67.

${ }^{86}$ IPN Poznań, UWP, sygn. 19/21, fot. nr 38, s. 38. 
parafii z Poznania. Służyłaby wówczas dalej polskim ewangelikom. Rzeczywistość wyznaniowa kształtowała się jednak inaczej. Lokalna gmina protestancka przez cztery wieki swej działalności w Osiecznej i okolicy nie zwiększyła swej liczebności. Poza tym przez cały ten czas wśród jej członków dominowali Niemcy, co niewątpliwie było też konsekwencją zaborów i postrzegania protestantyzmu jako wyznania niemieckiego, napływowego. Potwierdza to m.in. patriotyczna postawa osieckiego proboszcza, księdza Pawła Steinmetza (1876-1940) ${ }^{87}$, a także proniemiecka i antypolska pastora Wernera Niedera $(1880-1949)^{88}$.

Nie było możliwe odtworzenie dziejów przedmiotów wchodzących w skład wyposażenia obiektów niesakralnych. Większość ruchomości byłej parafii (np. księgozbiór biblioteki) nie została w ogóle zinwentaryzowana. Na ich temat brak jakichkolwiek wzmianek w aktach, a obecny ich los jest nieznany. Przypuszczalnie były one użytkowane przez powojennych zarządców, PPR i wyznaczone przez władze osoby. Niektóre ruchomości ze świątyni poewangelickiej trafiły do instytucji kościelnych. Dzięki temu ocalały od zniszczenia lub kradzieży.

Adres Autora:

mgr Adrian Gendera

Szkoła Doktorska

Uniwersytetu Wrocławskiego

Plac Uniwersytecki 1

50-137 Wrocław

adrian.gendera@gmail.com

https://orcid.org/0000-0002-9796-576X

\section{BIBLIOGRAFIA}

\section{Źródla archiwalne}

AP Leszno [Archiwum Państwowe w Lesznie], SPL [Starostwo Powiatowe w Lesznie], sygn. 70, 1317.

AP Leszno [Archiwum Państwowe w Lesznie], AO [Akta miasta Osieczna], sygn. 588; 702; 665; $683 ; 588 ; 590 ; 550 ; 571$.

AP Leszno [Archiwum Państwowe w Lesznie], PMRNOS [Prezydium Miejskiej Rady Narodowej w Osiecznej], sygn. 171.

AP Leszno [Archiwum Państwowe w Lesznie], WBPPL [Wojewódzkie Biuro Planowania Przestrzennego w Lesznie], sygn. 297.

IPN Poznań [Instytut Pamięci Narodowej i Komisja Ścigania Zbrodni przeciw Narodowi Polskiemu, oddział w Poznaniu], UWP [Urząd Wojewódzki w Poznaniu], sygn. 19/15; 19/25; 19/21.

Juchniewicz J. 2016. Relacja Józefa Juchniewicza, 07.12.2016 r., wywiad A. Gendera, Osieczna.

Nowak B. 2016. Relacja Barbary Nowak, 01.11.2016 r., wywiad A. Gendera, Osieczna.

Nowak L. 2016. Relacja Lidii Nowak, 07.12.2016 r., wywiad A. Gendera, Osieczna.

Wizja lokalna. 2019. Wizja lokalna autora [A. Gendery], 28.10.2019 r., Osieczna.

\section{Źródła i opracowania publikowane}

Binemann-Zdanowicz Dawid. 2009. Roszczenia majątkowe Kościoła Ewangelicko-Augsburskiego w Rzeczypospolitej Polskiej, w świetle ustawy z 13 maja 1994 r. o stosunku Państwa do Kościoła Ewangelicko-Augsburskiego w Rzeczypospolitej Polskiej, [w:] Polski protestantyzm w czasach nazizmu i komunizmu, red. J. Kłaczkow, Toruń, s. 372-400.

Birecki Piotr. 2012. Losy poewangelickich kościołów i budynków parafialnych na Pomorzu Nadwiślańskim po 1945 r., [w]: Kościoły chrześcijańskie w systemach totalitarnych, red. J. Kłaczkow, W. Rozynkowski, Toruń, s. 684-709.

Bogdanowicz Jerzy. 2013. Ziemia leszczyńska. Styczeń 1945, Leszno. 
Czwojdrak Dariusz. 2013. Duchowni ewangeliccy w Osiecznej w XVII-XX w., „Zeszyty Osieckie”, nr 21, s. 25-31.

Dekret 1. 1945. Dekret z dnia 2 marca 1945 r. o majątkach opuszczonych i porzuconych, „Dziennik Ustaw", nr 9, poz. 44 i 45.

Dekret 2. 1946. Dekret z dnia 8 marca 1946 r. o majątkach opuszczonych i poniemieckich, „Dziennik Ustaw", nr 13, poz. 87.

Dekret 3. 1946. Dekret z dnia 19 września 1946 r. o zmianie dekretu Prezydenta Rzeczypospolitej $z$ dnia 25 listopada 1936 r. o stosunku Państwa do Kościoła Ewangelicko-Augsburskiego w Rzeczypospolitej Polskiej, „Dziennik Ustaw”, nr 54, poz. 304.

Domasłowski Jerzy. 2005. Kościół Ewangelicko-Augsburski w Poznaniu i w Zachodniej Wielkopolsce w latach 1919-2005, Poznań.

Domasłowski Jerzy. 2009. Władze lokalne wobec parafii Kościoła ewangelicko-augsburskiego w Poznaniu, [w]: Władze wobec Kościołów i zwiazków wyznaniowych w Wielkopolsce w latach 1956-1970, red. K. Białecki, Poznań, s. 231-250.

Evangelischer Volkskalender. 1901. Evangelischer Volkskalender auf das Jahr 1901, Posen.

Frankiewicz Edward. 1986. „Osieczna. Zarys historyczny”, maszynopis, Opole.

Grelewski Stefan. 1937. Wyznania protestanckie i sekty religijne w Polsce wspótczesnej, Lublin.

Jędraś Stanisław. 2012. Osieczna i jej dzieje, Osieczna.

Kiec Olgierd. 2017. 500 lat protestantyzmu w Poznaniu, „Przegląd Wielkopolski”, nr 2, http://www. e-pw.pl/page.php/1/0/show/186/ (dostęp 03.11.2019).

Kłaczkow Jarosław. 2010. Kościół ewangelicko-augsburski w Polsce w latach 1945-1975, Toruń.

Kurpiewski Maciej. 2017. Historia wspólnoty ewangelickiej w Wejherowie i jej cmentarza w latach 1643-1951, „Gdański Rocznik Ewangelicki”, nr 7, s. 82-113.

Łuczak Tomasz. 2008. Dzwony kościelne w Osiecznej, „ZO”, nr 16, s. 36-40.

Małyszka Arkadiusz. 2004. Ewangelickie pozostałości w Poznańskiem, „Biuletyn IPN”, nr 3 (38), s. $72-73$.

Matelski Dariusz. 1997. Mniejszość niemiecka w Wielkopolsce w latach 1919-1939, Poznań.

Michalski Maciej. 2005. Osieczna (Storchnest). Dawne widoki, Osieczna-Poznań.

Sławiński Wojciech. 2009. Spory o nieruchomości Kościołów ewangelickich w Polsce w latach 1945-1947 - ujęcie historyczno-prawne. Zarys zagadnienia, [w]: Polski protestantyzm w czasach nazizmu i komunizmu, red. J. Kłaczkow, Toruń, s. 356-371.

Sroka Piotr. 2010. Wrocławskie władze wojewódzkie a przejmowanie kościołów ewangelickich przez administrację apostolską Dolnego Śląska, „Śląski Kwartalnik Historyczny Sobótka”, nr 3 (61), s. 339-354.

Suchecka Grażyna. 1998. Kościoły katolickie przejęte na cele kultu katolickiego w dekanacie Rozogi: w świetle dokumentów z Archiwum Archidiecezji Warmińskiej, „Rocznik Mazurski”, nr 3, s. 81-87.

Szczudłowski Piotr. 2001. Losy poewangelickich obiektów sakralnych na terenie diecezji gdańskiej po 1945 r., Lublin.

Taube Albert. 1899. Geschichte der evangelischen Kirchengemeinde Storchnest, Storchnest [Osieczna].

Ustawa 1. 1945. Ustawa z dnia 6 maja 1945 r. o majątkach opuszczonych i porzuconych, „Dziennik Ustaw", nr 17, poz. 97.

Ustawa 2. 1947. Ustawa z dnia 4 lipca 1947 r. o zmianie dekretu Prezydenta Rzeczypospolitej z dnia 25 listopada 1936 r. o stosunku Państwa do Kościoła Ewangelicko-Augsburskiego w Rzeczypospolitej Polskiej, „Dziennik Ustaw”, nr 52, poz. 272.

Ustawa 3. 1994. Ustawa z dnia 13 maja 1994 r. o stosunku Państwa do Kościoła Ewangelicko-Augsburskiego w Rzeczypospolitej Polskiej, „Dziennik Ustaw”, nr 73, poz. 323.

Zieliński Tadeusz Jacek. 2009. Prace Sejmu Ustawodawczego w 1947 r. nad stanem prawnym Kościołów protestanckich, [w]: Polski protestantyzm w czasach nazizmu i komunizmu, red.

J. Kłaczkow, Toruń, s. 341-355.

http://elka.pl/content/view/65945/80/ (dostęp 10.04.2019).

https://www.facebook.com/Towarzystwo-Ziemi-Osieckiej-349677798761999/ (dostęp 03.11.2019).

https://www.ipsb.nina.gov.pl/a/biografia/pawel-steinmetz (dostęp 06.11.2019). 
http://www.marcinblaszkowski.leszno.eu/13.html (dostęp 03.11.2019).

https://leszno.naszemiasto.pl/bojanowo-zachowa-przedszkole/ar/c1-5313903 (dostęp 08.10.2019).

https://leszno.naszemiasto.pl/ewangelicy-chca-zboru-i-pastorowki/ar/c8-5251829 (dostęp 08.10.2019).

https://leszno.naszemiasto.pl/ewangelikom-co-ewangelickie/ar/c8-5725021 (dostęp 08.10.2019).

https://opuszczone-koscioly-ewangelickie.blogspot.com/ (dostęp 03.11.2019).

http://powstancywielkopolscy.pl/pl/ (dostęp 16.02.2019).

\section{The history of use of post-Evangelical property in Osieczna after 1945}

Evangelical property, which is the property of local religious communities and at the same time a testimony of their history, material and spiritual culture, in the winter of 1944/1945 became abandoned German property. The evacuation of the German (often evangelical) population led to the cessation of activities of numerous evangelical parishes in, among others Greater Poland, including the city of Osieczna and surrounding villages. The post-war history of the use of post-Evangelical properties was twofold: church and secular. In Osieczna, all real estate served secular, economic and social purposes. Part of the temple's equipment and church (catholic) purposes. The local protestant parish never revived, and its goods were partly destroyed and partly blended into the small-town everyday life and survived to this day. 